\title{
Tri Rismaharini's Speech, The Mayor of Surabaya : A Critical Discourse Analysis (CDA)
}

\author{
SUEB \\ University of Wijaya Kusuma, Surabaya Indonesia
}

\begin{abstract}
Language plays the important roles in everyday life for human being. This article relates to the governmental leader using language in communicating with the community or people she leads in order to convey her thoughts of programs of work which will be implemented. It elaborates the usage of Tri Rismaharini's language as the Mayor of Surabaya Indonesia with Critical Discourse Analysis (CDA) Approach. The method, meanwhile, used in the research is qualitative descriptive and it is found the elements of language usage and content of speech providing a macro-themed structure of texts.
\end{abstract}

Keywords: Speech, Critical Discourse Analysis

DOI: $10.7176 / J L L L / 76-03$

Publication date: February $28^{\text {th }} 2021$

\section{Introduction}

Language plays an important role in everyday life. Every person in a variety of professions must use language in carrying out his or her life activity, be the profession as a teacher, a lawyer, a journalist, a broadcaster, a businessman, a company leader, a regional leader, or a country leader, and so on. Of course they use a language in communicating with the society in accordance with their respective professions. Thus it can be said, that the language is the main function as a means of communication, either communicate directly face to face or communicate through writing.

This is in accordance with what is presented by Saputro, (2013: 1), Indonesian language is currently used by the Indonesian people as the main communication tool in everyday life. Our society ranging from intellectuals to the laity, urban communities to villagers scattered throughout the country are using the Indonesian language as a means of communication. Even it is in a state meeting starting the plenary session of the President, the general assembly of MPR/DPR up to the village meeting or rembug desa (Javanese term) all are using Indonesian language. This shows how important the Indonesian language in the life of society, nation, and state. To be a nation implies that Indonesian language is needed in communication among Indonesian community members in everyday life. It means that the Indonesian language plays an important role in regulating life of the nation in a broad sense. In the state level, the role of Indonesian language is directed more to be used in official forums or state.

Especially for governmental leaders, they are expected to use the language in communicating with the community or the people they lead. Leaders can use good and correct sentences, proper intonations, and mime pantomimes that can attract attention in order to convey the thoughts or programs of work that are and will be implemented. With the appearance of the language in question, it is better still supported by the implementation of appropriate programs in accordance with the priorities and needs of the community.

Based on the background, the author raised the title of Tri Rismaharini's Speech, the Mayor of Surabaya: A Critical Discourse Analysis (CDA). The reason of the author raised this title is that he wants to describe the use of Tri Rismaharini's language as the Mayor of Surabaya in leading Surabaya with Critical Discourse Analysis approach.

\section{Review of Related Literature}

This review of related literature deals with the basic concepts of language or linguistics, speech, and Critical Discourse Analysis (CDA). According to Lyons (1995: 1), linguistics can be defined as a scientific study of language. This definition hardly gives a sufficient picture to the reader, and does not give a positive indication of the basic principles of this field of study. This definition may be clarified slightly by elaborating in more detail the notions contained within the 'scientific' boundaries. In the meantime, it is sufficient to say that the purpose of scientific study or study of language is the investigation of language through regular observations which are empirically verifiable whether or not it refers to a general theory of language structure.

The structure of the language includes: sounds and words, phonology, grammar, and semantics, "double articulation language", "level" versus "side", and "expression" versus content (Lyons 1995: 54). Thus, the linguistics in this study highlights elements of words, sentences, styles, and intonations. This elaborates:

\section{A. Speech}

The term of speech is a term that can be equated with public speaking (speaking in public). Public speaking has a definite format that usually includes time, when the audience should gather and when the speech should begin, 
even when the speech will end (Bormann, 1991: 129).

In this research, speech is an opening speech of Tri Rismaharini, Mayor of Surabaya, in carrying out daily duties in her working area of Surabaya.

\section{B. Critical Discourse Analysis}

Critical Discourse Analysis, hereinafter referred to as (CDA), is a study in society using a critical approach. Historically, CDA has links with Halliday (1986: 36) on instrumental linguistics. This instrumental linguistics is a study of languages to understand other worlds, such as social system through language analysis. As a discourse analysis, CDA uses many concepts using descriptive approaches. Various technical terms are used by CDA experts (although there is little difference in utilization). For example, they are the terms of transitivity, passivity, coherence, and so forth (Fawley, 1996, Van Djik, 2001, Fairclough, 1995 and 1998).

The discourse by Van Dijk is described as having three dimensions, namely, text, social cognition, and social criticism. He combines the three dimensions of the discourse into a single unit of analysis. In the text under study, the focus of the study is how the structure of the text and discourse strategies are used to assert a particular theme. Social cognition studies the induction process of journalists. While the third aspect of social criticism studying the building of discourse which developed in society on a problem (Darma, 2009: 88).

Van Dijk in Eriyanto (2003: 225, 260, 271), says (1) The text consists of several structures/levels in which each part supports each other, namely, macro structure, superstructure, and microstructure. (2) Social cognition: the mental consciousness of the journalist who formed the text, for example the Ambon case, the journalist's mental consciousness in looking at the Ambon case. What is the belief, knowledge, and prejudice of journalists against Islamic or Christian groups in Ambon. (3) Social analysis, in this analysis there are two very important points; power and access. (a) The practice of such power as the possession possessed by something of a group (members), a group to control groups (members) of other groups. This power is generally based on the ownership of valuable resources, such as money, status, and knowledge. (b) How is access between groups within community. Elite groups have greater access than the non-powerful groups. Therefore, a more powerful group has a greater chance of having access to the media and a greater opportunity to influence the audiences' aims.

In CDA discourse is not solely understood as a language study. In fact, the critical discourse analysis uses the language in the text, but the language analyzed the CDA is different from the study of language in the traditional sense. The language analyzed by the CDA is not only the language aspects, but also related the context. Context in this case means language is used for certain purposes including power practice (Darma, 2009: 51).

\section{Research Method}

The method used in this research is a qualitative approach. Bogdan and Taylor (1975: 4) states that, "qualitative methodologies refer to research procedures which produces descriptive data: people's own written or spoken words and observable behavior".

The use of qualitative methods in this research used several considerations, among others (1) data sources in this research is a fair situation, namely, the mayor's speech in government offices; (2) the researcher as a research instrument conducts observations, downloads speech scripts from the internet, interviews with resource persons, and records, (3) speech data/text collected by the majority of descriptive data does not prioritize numbers or statistics but does not reject quantitative data, (4) this research prioritizes process and product, (5) this research tries to find element of language and content of speech; (6) research prioritizes data directly from the field or government office; (7) This research prioritizes the view that is concerned with the view of informants in viewing and interpreting the world in terms of its establishment, (8) this study performs data analysis from the beginning of the research to the end of the study or during the research, (9) this research is not to test the hypothesis based on certain theories, but to build or find theories based on the data collection (Nasution 1988: 9-11; Moleong, 1990: 4-7).

\section{Result and Discussion}

In this discussion the author uses three speeches or opening speeches of Tri Rismaharini, Mayor of Surabaya, on October 12, 2013: The Opening Speech to Receive Taman Nginden Intan Surabaya; February 24, 2014: The Opening Speech at the Garbage Care Movement; and February 26, 2014: The Opening Speech is the Opening of Baksos (Cooperation) with Integrated Services. Of the three Opening Speeches, the researcher analyzed two dimensions, namely, (1) the dimensions of the text, and (2) the dimensions of social cognition.

\section{The Dimensions of the Text}

From the three speeches, it was found that the theme of the Opening Speech Script is as follows:

"Waste management aims to create a clean and healthy environment. However, it is only an intermediate objective. The ultimate goal is to create a healthy society in order that human resources are also good " (Risma, 2014: 70-75). 
Based on the above quotation, it can be explained that in the event of "Garbage Care Movement" on February 2, 2014, Tri Rismaharini raised the theme of macro structure, meaning that the waste must be realized by managing this waste with good systems and procedures, so as to create a clean and healthy environment. However, this condition must be followed up to achieve the main goal which is to create a healthy society so that the quality of human resources is also good in accordance with the expectations of society and government.

Besides, the other theme is also found, namely:

"Baksos with Integrated Service at RW IX Kelurahan Tambakrejo, Simokerto District, organized an effort to improve services to the community" (P1 Risma, 2014: 10-15).

Based on the quotation, it can be explained that, Tri Rismaharini raised this theme with the hope that the City Government implements the social services in the framework of integrated or united services.

In this case, the City Government provides services for the community in the integrated manner. The integrated service involves many Regional Work Unit (SKPD), such as Health Service, Education Service, Bapemas KB, Dispendukcapil, Office of Manpower, Social Services, Department of Management of Buildings and Land (DPBT), Department of Agriculture, Cooperation and SMEs, Office of Youth and Sport. The service to the community is executed in an integrated way so that this can be effective and efficient, in addition, the public can get free service from the city government. Thus, the integrated service is very useful and very helpful for the people, especially the poor people.

\section{The Dimensions of Social Cognition}

Social cognition is a mental consciousness of journalists who form the text, for example, Tri Rismaharini's activities in journalists' mental awareness in viewing the activities, how the trust, knowledge, and prejudice of journalists against such activities. Social cognition in the Tri Rismaharini's opening speech script is as follows.

"It all departs from the Surabaya City Government's commitment to provide a decent living for the citizens of the city" (P1 Risma, 2014: 25-30).

"Besides, the people of Surabaya also succeeded in increasing their economy by integrated waste management, through the sale of waste recycling products" (P1 Risma, 2016: 55-60).

In mental awareness, journalists or citizens provide positive social cognitive responses, that the first sentence shows the Surabaya City Government to make a strong commitment to provide decent living for the citizens of the city. With the commitment given to the people of Surabaya, they managed to improve their economy. The second sentence by managing the integrated waste they can finally sell the results of recycled waste products, so it can produce a useful economy for the benefit of the people of Surabaya.

"The role of cadre has really been an agent of change in the

increasing quality of Surabaya's environment over time"

(Risma, 2014: 30-35).

The value of social cognition that emerged from the community, namely, the leadership of Tri Rismaharini as the Mayor, succeeded in mobilizing the tough cadres and can actually serve as agents of change for the city of Surabaya. Thus, these cadres can improve the quality of the Surabaya environment from time to time periodically, so that the environment of Surabaya can be maintained even upgraded from year to year.

"This success is also supported by the activities of villages that are trying to create a clean, green and beautiful environment" (P1 Risma 2016: 30-35).

Based on the above quotation of social cognition that emerged from the community, that the Surabaya leader succeeded in motivating the people, tapped their heart with high awareness which motivates them to hold races between villages to realize the environment clean, green and beautiful.

"The city of Surabaya is a city that is concerned about

environmental stewardship" (P1 Risma, 2014: 20-25).

"The city of Surabaya has been known as a city that has many parks, so they can present green space as the lungs of the city" (P3 Risma, 2013: 10-15).

Based on the two quotations above, there is a basic social cognition of society with her elegant leadership, Tri Rismaharini, the Mayor of Surabaya, is very concerned about the arrangement of the environment, in this case, it is evidenced by the presence of so many parks, so, that the green spaces become the lungs of the city. This beautiful garden can be used by the residents to relax and interact with other citizens as the utilization of the city park in question. In her leadership, there are two elements:

Power

Power can be observed in the following quotation.

"Therefore, I hope that people can use it, especially for the poor to get

free health care and other services" (P2 Risma, 2014: 15-20).

The quotation above shows that Tri Rismaharini as a mayor has an extraordinary power that is not owned by others. With her status as the mayor, she has extensive social activities. She can command the poor to utilize 
the free health care and other services on the basis of her power.

In addition, Tri Rismaharini's power appears in the following quotation.

"I am sure with our hard work support together, the ideals to realize Surabaya as a

beautiful city, clean, neat, beautiful, and healthy will be realized" (P3 Risma, 2013: 35-40).

By using the sentence I am sure ..., this shows that Tri Rismaharini individually shows her ego as a leader to show to the community that she is a leader who has full power in showing her performance to work hard together to realize the city of Surabaya as a beautiful city, clean, neat, beautiful, and healthy.

Access

In addition to the power of Tri Rismaharini's opening speech also contains access as it can be seen at the following quotation.

"Therefore, I hope that people can use it, especially for the poor to get free health care and other services" (P2 Risma, 2014: 15-20).

The above quotation provides access for Tri Rismaharini to penetrate the support of the Health Office to carry out her orders. In addition, electronic mass media or print media will disseminate or broadcast broadly about free health services and other services for the welfare of the community. The provincial or central government's provincial fertility path will appreciate this positive activity.

\section{Conclusion}

Based on the data analysis above, finally the author draws the following conclusions.

A. The open speech texts of Tri Rismaharini, the Mayor of Surabaya, use a macro-themed structure: "Caring for the waste should be realized by managing this waste with good systems and procedures, thereby creating a clean and healthy environment" and "Efforts to Improve Services to the Community".

B. Positive social cognition, that (1) the Surabaya City Government has made a strong commitment to provide decent living for the citizens of the city and they succeed in improving their economy. (2) By managing integrated waste they can eventually sell the products of recycled waste products to produce economic benefits for the citizens of Surabaya. (3) The value of social cognition that emerged from the community, that is, Tri Rismaharini's leadership as mayor succeeded in mobilizing the cadres who are tough and can actually act as agents of change of Surabaya city, so as to increase the environment quality Surabaya periodically.

C.(1) Tri Rismaharini as a mayor has extraordinary power. With her status as mayor she has extensive social activities, which can instruct the poor to use free health care and other services on the basis of her power. (2) Quotation of Tri Rismaharini's opening text includes access to give support from various agencies, one of which is the Health Office to carry out her orders, electronic mass media or print media will disseminate or broadcast broadly about free health services and other services for the welfare of the community, the provincial or central government will appreciate this positive activity.

\section{Acknowledgements}

I would like to express my deep gratitude to Civitas Academica of Universitas Wijaya Kusuma Surabaya Indonesia which had facilitated me to conduct the research and also to IISTE (The International Institute for Science, Technology and Education) which had accepted and published the article.

\section{References}

Bogdan, Robert and Steven I Taylor. 1975. Introduction to Qualitative Research to the Social Sciences. New York: John and Sons, Inc.

Bormann, Ernest G. 1991. Retorika Suatu Pendekatan Terpadu. Jakarta: Erlangga.

Darma, Yoce Aliah. 2009. Analisis Wacana Kritis. Bandung: Yrama Widya.

Eriyanto. 2003. Analisis Wacana. Yogyakarta. LKIS.

Halliday, M.A.K. 1985. An Introductional to Functional Grammar. London: Edward Arnold Publishers. Ltd.

Lyons, John. I. Soetikno. 1995. "Pengantar Teori Linguistik": Introduction to Theoretical Linguistics. Jakarta: PT Gramedia Pustaka Utama.

Moleong, Lexy J. 1990. Metodologi Penelitian Kualitatif. Bandung: Remaja Rasdakap.

Nasution. 1988. Metode Penelitian Naturalistik Kualitatif. Bandung: Tarsito.

Saputro, Sueb Hadi. 2016. Pendidikan Bahasa Indonesia sebagai Media Revolusi Mental Generasi Muda Masa Depan. APPI BASTRA: Prosiding Seminar Nasional Bahasa dan Sastra.

Van Dijk, Teun A. 1997. “Critical Discourse Analysis”. Diambil dari Analisis Wacana. 2009. Bandung: LKIS. 